Таким чином, серед митців ленд-арту спостерігаються тенденції звернення до надбання мистецької спадщини значною мірою зумовлені використанням техніки різьблення як джерела глибинних історикокультурних традицій.

\title{
Лiтература:
}

1. Imperadori M., Clozza M., Vanossi A., Brunone F. Digital Design and Wooden Architecture for Arte Sella. Digital Transformation of the Design, Construction and Management Processes of the Built Environment. 2020. C. 161-173. DOI: 10.1007/978-3-030-33570-0_15

2. Гальчинская О., Васильева Е., Пашкевич К. Использование техники плетения из природных материалов в искусстве ленд-арт. Revista de științe socioumane. Chişinău, 2020. Nr.1(44). C. 95-106. URL: https://ibn.idsi.md/ro/vizualizare_articol/109949 (Last accessed: 11.11.2020).

3. Сайт Urs-Peter Twellmann URL: https://twellmann.ch/portfolio/ outdoor-sculptures/ (Last accessed: 11.11.2020).

4. Сайт Stuart Ian Frost. URL: https://stuartianfrost.com (Last accessed: 9.11.2020).

5. Сайт Debra Bernier URL: https://www.facebook.com/ShapingSpirit (Last accessed: 11.11.2020).

DOI https://doi.org/10.30525/978-9934-26-004-9-105

\section{ІНКЛЮЗИВНИЙ ДИЗАЙН У МОДІ ХХІ СТОЛІТТЯ: СОЦІОКУЛЬТУРНІ, ЕТИЧНІ ТА ХУДОЖНІ АСПЕКТИ}

\author{
Дерман Л. М. \\ кандидат філософських наук, дочент, \\ завідувач кафедри дизайну та реклами \\ факультету філософії та суспільствознавства \\ Національного педагогічного університету імені М. П. Драгоманова \\ м. Київ, Украӥна \\ Розвиток інклюзивного дизайну бере свій початок у XX столітті. \\ Історія його виникнення та еволюції пов'язана 3 наслідками, що \\ принесли дві світові війни та розвиток науки, медицини, що дозволило \\ суттєво продовжити життя людей, в тому числі й тих, хто мав \\ фізіологічні порушення: опорно-рухової системи, сенсорної тощо.
}


Кількість людей, що виживали після травм, які раніше вважалися смертельними, також збільшилася.

Вперше за боротьбу проти дискримінації людей, що мають фізіологічні відхилення згідно медичних норм стали Європа, США, Японія. У 70-ті роки розгорнувся рух «Без бар'єрів», що мав суттєвий вплив на законодавчу базу 49 американських штатів, які включили поправки, що стосувалися будівництва споруд зорієнтованих на стандарти доступності.

Спершу інклюзивний дизайн передбачав доповнення вже існуючих рішень у будівництві та середовищі загалом, що були розраховані на середньостатистичного споживача [3].

Незважаючи на те, що інклюзивний дизайн передбачає проєктування середовища, що максимально зручне для усіх, проте все ж головний принцип - це відмова від усереднення. Позаяк різноманітність людей та їх потреби неможливо привести до середнього значення. Адже речі, які створені для середнього користувача не можуть бути зручними для переважної більшості. Натомість $є$ спосіб проєктування, що називають «дизайном до крайнощів» (design to the edges), коли рішення розробляються для споживачів віддалених кінців спектра. У широкому розумінні, інклюзивний дизайн - це дизайн усіх речей, які враховують потреби кожного, створюють рівні умови та забезпечують автономність [6].

Інклюзивний дизайн орієнтований на процеси проєктування, в основі яких етичне ставлення та відповідальність перед досвідом користувача.

Сучасний світ пропонує більше дизайнерських речей для домашніх тварини, ніж для людей, що мають певні фізіологічні відхилення від медичної норми. Зокрема дизайнери розробляють колекції одягу присвячені уподобанням різних субкультур (хіппі, готи), проте не інклюзивний одяг.

В кожній культурі $є$ багато інших субкультур. Часом серед них виникає неприйняття чи певна напруга. Саме це робить популяризацію $\mathrm{i}$ роз'яснення теми інклюзивного дизайну в суспільстві настільки важливими.

Етика дизайну стосується морального відповідального вибору в дизайні. Вона визначає те, як дизайнери працюють 3 клієнтами та колегами, яким чином організують процес проєктування, як саме визначають функції продуктів та як оцінюють етичну значимість або моральну цінність вироблених речей.

Принципи проєктування адаптивного одягу полягають у тому, що він повинен давати можливість бути незалежним тим, хто цього найбільше 
потребує, вироби мають відповідати модним тенденціям, бути універсальними та функціональними [3].

Першою, хто відкрила шлях у світ моди інклюзивним моделям у 1998 році - паралімпійська рекордсменка Еймі Маллінз, яка брала участь у показі Олександра Маккуїна на дерев'яних чоботах від кутюр в стилі Людовіка XIV з майстерним різьбленням. Після шоу Маккуїна протягом п'ятнадцяти років в світі моди не відбувалося нічого, що б популяризувало чи звертало увагу на людей 3 фізіологічними відхиленнями. У 2005 році у своєму показі відомий дизайнер Джона Гальяно на подіум вивів високу модель поруч із якою йшов карлик. Дефіле було побудовано на контрастах, проте воно не присвячувалося проблемам інклюзивного дизайну, а тільки було покликано створити шоу, піар.

Відомі будинки моди наразі не створюють колекції адаптивного одягу, проте часом розробляють окремі лінійки чи вироби, а також запрошують інклюзивних моделей до рекламних кампаній та участі в програмах тижнів моди в Нью-Йорку, Токіо, Берліні тощо [4].

Проте інклюзивна мода більш популярна серед виробників сегменту мас- маркет. Так британський виробник одягу та аксесуарів River Island запросив дітей 3 особливостями розвитку для участі в рекламній кампанії.

Еволюція цього сегменту ринку змушує компанії відповідати потребам, запитам своїх клієнтів та нести відповідальність за виготовлений продукт. Проєктування адаптивних речей - повільний процес, позаяк суспільство часто необізнане й не усвідомлює глибини ситуації. Наразі не так багато брендів, які пропонують лінійки адаптивного одягу, серед лідерів у цій сфері: Ffora, Томмі Хілфігер та Хромат лідери даного сегменту[5].

У 2016 році Томмі Хілфігер розробив першу колекцію адаптивного одягу для дітей, а згодом бренд запропонував й інклюзивне вбрання для дорослих [5].

Адаптивний одяг має такі загальні характерні особливості як: застібки з магнітними кнопками, регульовані подоли та застібки-липучки тощо. Така функція може бути корисною для людей похилого віку, дітей, людей з ампутацією та осіб із синдромом Дауна, ДЦП тощо. У людей $з$ ДЦП дуже різкі спастичні рухи, які вони не можуть контролювати, тому окремі деталі, що піддаються навантаженню, мають бути зроблені 3 міцних матеріалів. Використання гудзиків у якості застібок - недоречні, навіть якщо людина одягається не самостійно. При проєктуванні такого одягу, краще використовувати застібки, що розташовані по діагоналі 
виробу. Існує й спеціальне взуття, що легко одягається та знімається. Наприклад Nike випустив адаптивну модель кросівок. Бренд Billy використовує принципи універсального дизайну в проєктуванні взуття та інноваційну технологію FlipTop [2; 4].

У досліджені французького професора філософії та соціології Жиля Липовецького, який вводить поняття «феєрія видимості» в роботі «Імперія ефемерного. Мода та ії доля в сучасному суспільстві» говориться про те, що для людини зрячої вбрання століттями служило очевидним соціальним маркетом, свідченням достатку тощо. Для людей незрячих, це сторона іншої медалі [1].

Наприклад, Apple розробив розумні сорочки для людей, що мають проблеми зі слухом та зором. Користувачі отримують підказки за допомогою спеціальної сорочки, яка має покриття, що направляє власника тактильними сигналами. Слабозорі люди отримують голосові команди від одягу, що направляє їх.

Існують певні стандарти, щодо проєктування адаптивного одягу. Вимоги до одягу для незрячих людей мають певну специфіку. Наприклад, головний убір повинен мати піддашок, щоби уникати ударів головою. Штани мають бути 3 м'якими або жорсткими вставками, що розташовані нижче лінії колін, так як саме цією зоною, люди з поганим зором вдаряються найчастіше [3].

Одяг для людей з аутизмом та сенсорними проблемами не повинен містити незручних деталей в одязі, таких як ярлики, що викликають свербіння тощо. Бажано, щоби вбрання було зібрано плоскими швами та містило зручні відділення (кишені) для розташування в них персональних пристроїв відстеження тощо [4].

Бренд Silvert пропонує адаптивний одяг для людей, що прикуті до інвалідних візків. Особливості такого вбрання зумовлені проблемами 3 кровообігом, набряком ніг, адже постійне сидяче положення створює проблеми $з$ тиском, викликає чутливість до швів тощо. Тому в даному контексті доречне проєктування одягу, що зігріває кінцівки, чи то використання тканини, що має функцію підігріву. Для інвлідівспинальників використовуються водонепроникної тканини, а самі вироби можуть мати регульовані манжети для зміни довжини рукава. У людей, що прикуті до інвалідних візків як правило сильно брудняться зони на рукавах і штанах, тому тканина повинна бути такою, щоб ії легко можна було почистити [2].

Перспективи розвитку етики інвалідності. Концепція інклюзивного дизайну проходить період трансформації. Ї̈ можна досліджувати в рамках різних парадигм, які відрізняються підходами, перспективною 
розвитку, етичною стороною питання та практичною реалізацією. Тему інклюзії можна розглядати в контексті діалогу між медичною та соціальною моделлю сприйняття, або як їх взаємодію, що передбачає необхідність міждисциплінарних дискусій, що забезпечить вирішення питання щодо поінформованості про дану проблему та можливі шляхи іiі вирішення.

\section{Література:}

1. Липовецкий Ж. Империя эфемерного. Мода и ее судьба в современном обществе/пер. Ю. Розенберг. Москва: Новое литературное обозрение, 2012. $336 \mathrm{c}$.

2. Нагорна 3. В. Класифікація методів трансформативного формоутворення в дизайні одягу. Харків: Вісник ХДАДМ № 4, 2015. C. 87-89.

3. Айя Рено. Что такое инклюзивный дизайн. 25.08.2017. URL: https://te-st.ru/2017/08/25/what-is-inclusive-design/ (дата звернення: 16.10.2020)

4. Eliza Huber. People With Disabilities Deserve Great Style - \& I've Made It My Life's Work. 24.07.2020. URL: http://surl.li/gufs (дата звернення: 22.08.2020)

5. Tommy Hilfiger Adaptive. Branding, Photography, Print, Social Media. 2019.URL:http://www.katherinerohlfing.com/home/2019/5/20/tommyhilfiger-adaptive (дата звернення: 24.08.2020)

6. Що таке Універсальний Дизайн? https://ud.org.ua/informatsiya/ shcho-take-universalnij-dizajn (дата звернення: 28.10.2020) 